\title{
PROTECTION

\section{RUINS OF SACRED BUILDINGS: IDEOLOGICAL MESSAGE AND PROBLEMS OF ITS PRESERVATION}

\section{KRASNY Piotr ${ }^{1}$}

${ }^{1}$ prof. dr hab. Piotr Krasny, Institute of Art History, Jagiellonian University https://orcid.org/0000-0001-8726-1200

ABSTRACT: The ruin is a building, whose shape is deformed and decoration have suffered significant loses. So the viewer's attention is attracted by the ideological message of ruins, which is always different from the set of meanings of the complete edifice, and often contradicts it. This is clearly seen in the case of sacred buildings. In the 16th and 17th centuries Roman Catholic writers claimed, that the ruins of pagan temples in Rome are monuments of the ancient Roman Empire's power, but their current state clearly shows the defeat of paganism and triumph of Christianity. The prelates thought that it was necessary to take care of the ruins, but they should not be rebuilt. Protestant writers in the British Isles took a similar attitude to the local ruins of monastic temples, seeing in them a clear manifestation of the fall of the "papist religion" and the triumph of Protestantism. During the French Revolution, remains of the ruined churches were consciously preserved as monuments of the decline of Christianity and the triumph of the new cult of reason. So rejection of the religion granted protection to ruins of sacred buildings. However the religious indifference growing in many communities causes problems with determining the place of such ruins in public space. Reducing them to the role of bizarre "street furniture" (eg the church of Saint-Livier in Metz), causes their ideological neglection, often contributes to their material destruction. Preventing such situation seems to be an important challenge for conservators dealing with the problem of "permanent ruin".

KEY WORDS: Permanent ruin, church architecture, meaning of ruins 
Churches make good subjects for symbolic ruins ${ }^{1}$.

In the early modern period, antique sculptures found in Rome and all over Italy were commonly subjected to reconstruction. Ancient deities were recognized in the fragments and the debris, they were excavated or found among the rubble, and according to this identification, heads, limbs, and other attributes were attached thereto ${ }^{2}$. Ruins of pagan temples were treated altogether differently: any serious reconstruction was most consistently avoided, despite the fact that it would have been relatively easy to execute - by virtue of the existence of highly typical spatial solutions used in the sacred architecture of antique Greece and Rome. Sebastiano Serlio (1475c.1554), Andrea Palladio (1508-1580), Vincenzo Scamozzi (1548-1616), and other architects reproduced the appearance of specific temples on the pages of their treaties, but the results of these studies were never transferred onto the real space ${ }^{3}$. The reasons for such a dichotomy in the approach to various types of artistic heritage of pagan antiquity seems to lie in the religious attitudes of early modern Romans and other residents of Italy, and above all, in the fear that paganism might be thus propagated among the common people.

The reconstructed images of the deities found their way to private collections of popes, cardinals, prelates, and the most affluent secular people, who valued these sculptures only because of their beautiful forms, well aware that they portrayed the non-existent "idols". A similar attitude was presented by the few visitors, likewise belonging to the elite of the society, who were also admitted and allowed to see the collections of ancient sculptures. Among such audiences, these statues were incapable of arousing fascination with the pagan religion, and therefore there was no fear that they could become a source of scandal ${ }^{4}$. Although the greatest rigorists, such as the Archbishop of Bordeaux, François d'Escoubleau de Sourdis (1574-1628), criticized their colleagues from the College of Cardinals for placing the images of mythical goddesses and nymphs in their homes, their only fear was that the beautiful naked bodies of these statues could move excessively the imagination of the prelates who were obliged to maintain celibacy ${ }^{5}$.

Ginsberg R., The Aesthetics of Ruins, Amsterdam: Rodopi B.V, 2004, p. 109.

2 Rossi Pinelli O., Chirurgia della memoria. Sculture antice e restauri storici, [in:] Settis S. (ed.), Memoria del antico nellarte italiana, Vol. 3, Torino: Giulio Einaudi Editore, 1986, pp. 205-226; Sénéchal Ph., Resaturations et remplois de sculptures antiques, Revue de l'Art, 79, 1988, pp. 37-51; Montagu J., The Influence of the Baroque on classical Antiquity, [in:] Beck H., Sabine Schulze S. (ed.), Antikenrezeption im Hochbarock, Berlin: Gebr. Mann Verlag, 1989, pp. 85-108; Sparti D.L., The Rebirth of ancient sculpture in 17th Century Rome, [in:] Bacchi A., Coliva A. (ed.), Bernini, Milan: Officina Libraria, 2018, pp. 75-83.

3 Karmon D., [in:] The Ruins of the Eternal City: Antiquity and Preservation in Renaissance Rome. Oxford: Oxford University Press, 2011, pp. 47-118.

4 Seznec J., The Survival of the Pagan Gods: The Mythological Tradition and Its Place in Renaissance Humanism and Art, Transl. Sessions, B. F. Princeton: Princeton University Press, 1995; Hertklotz I., Scavi, collezionisti ed eruditi nella Roma del Seicento, [in:] Hertklotz I., La Roma degli antiquari. Cultura e erudizione tra Cinquecento a Settecento, Roma: De Luca Editori, 2012, pp. 121-135.

5 Montanari T., La libertà di Bernini. La sovranità dell'artista e le regole del potere, Torino: Giulio Einaudi Editore, 2016, p. 13. 


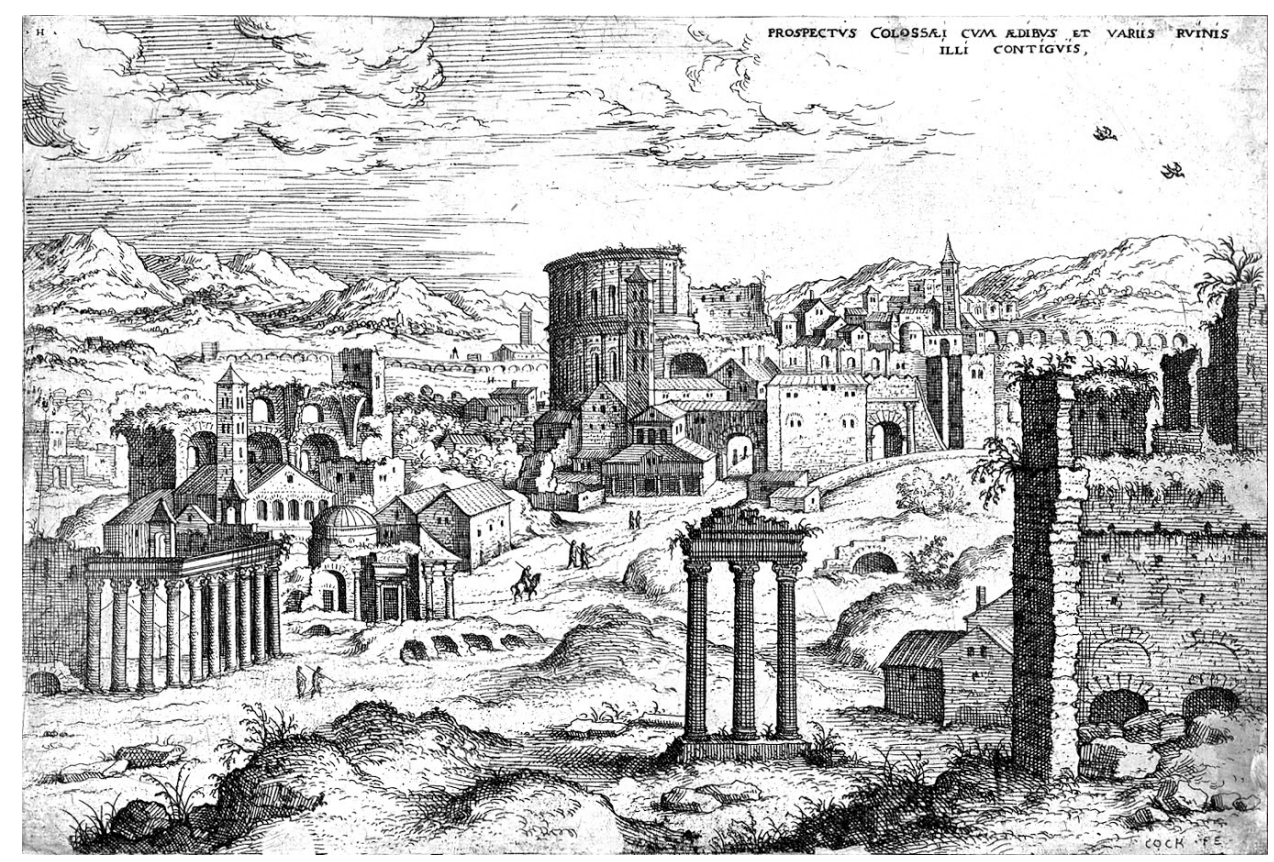

Fig. 1 Colosseum and ruins of the Forum Romanum, Copperplate of Hieronymus Cock, 1551

A completely different reception was likely in the case of temples, which were easily accessible to anyone in the public space. Even their remains evoked admiration by virtue of their very vastness, which overwhelmed the churches that stood next to them (Fig. 1). In architectural treaties and guidebooks, the aphorism "How great was Rome, her ruins instruct" was frequently repeated $^{6}$. The extraordinary magnificence of these fragments could, therefore, arouse dangerous interest in pagan religion in the eyes of unprepared spectators, and even expose them to the temptation of comparing Christianity with the superstitions that it had since conquered ${ }^{7}$. This was the attitude of the learned Benedictine, Gregorio Cortese (1483-1548), who proclaimed in a letter to his confrere Luciano Degli Ottoni, written in 1538, that he admires the Roman ruins "as monuments of power", but that he is also "unable to forget about the blood of Christian martyrs

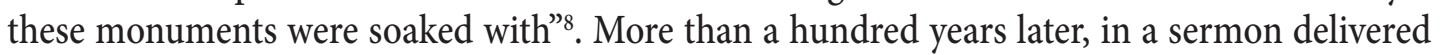
on the occasion of the translation of the relics of Pope-martyr Simplicius I to Milan, Charles Borromeo (1538-1584) preached that the ruins of ancient temples preserved in Rome show the extreme humiliation of the power of the pagan empire, whereas the well-preserved early Christian churches ostentatiously express the triumph of Christianity. This prelate reiterated: "the emperors Vespasian and Trajan, when they were at the height of power, erected splendid

\footnotetext{
6 Hui A., The Poetic of Ruins in Renaissance Literature, New York: Fordham University Press, 2017, p. 53.

7 Tschudi V. P., Baroque Antiquity: Archaeological Imagination of Early Modern Europe, Cambridge: Cambridge University Press, 2017, pp. 149-174.

8 Piva P., Laltro Giulio Romano: Il Duomo di Mantova, la chiesa di Polirone e la dialettica di Medioevo, Quisnello: Ceschi, 1998, pp. 54-55.
} 
temples to honour themselves. Where are these temples now? They fell into ruin, and there is hardly any trace left of them. All their vain splendour has gone. But churches, temples, and basilicas built to honour the saints and their relics continue in eternal glory. How lofty they are, and vast, how magnificent and how wonderfully decorated, how luminous and surpassing everything with their magnificence".

In a similar way, Jesuit Gregory Martin (c. 1542-1582) preached to English-speaking pilgrims coming to Rome, describing the fall of temples and monuments in his guidebook, drafted in 1581: "wherein old Rome in the time of infidelity did not take all their glory and the pride of their empire". Pointing to the ruined pagan buildings, he asked readers rhetorical questions, such as: "Where all this beauty was upon the seven hills, what is there now but desolation and solitariness?" He contrasted these buildings with the numerous churches of Rome, which invigorated and roused the devotion among the congregation by virtue of their very splendour, and he summarized his arguments with the statement: "And here gentle Reader see and consider with me a little further, how in Rome Christianity has succeeded Paganism, the Kingdom of Christ overthrown the Empire of Satan"10. In order to illustrate such an important lesson, repeated in many other descriptions of papal Rome during the Counter-Reformation period, it was certainly worth keeping the numerous ruins of pagan temples alive, and that, in the early modern era required not merely avoiding the demolition of these buildings, but also quite intensive efforts aimed at protecting them against the ultimate collapse ${ }^{11}$.

Counter-Reformation writers active in Rome saw very clearly that the temples brought to the state of ruin ceased to be a sign of power of the religion which they used to serve, and instead began to manifest the downfall of that religion with great eloquence. Martin's countrymen also attributed such significance to the ruins of pagan cult buildings in England, an example of which can be found in a particularly crude statement by Robert Gay about Stonehenge (1660). This antiquarian stated that the hand of God had overthrown this idolatrous altar while "reserving so much of its standing," because he wanted to preserve the memory, for ages to come, of humiliating the religion of druids, whose relics are now used by "dogs to such vomit, or sows to wallowing in such mire" ${ }^{12}$. In the Kingdom of England, however, the picture of a ruined temple did not usually serve the affirmation of Catholicism; sometimes, it was cited as an argument against this faith. Monks were considered the most important propagators of "papist persuasion", and therefore in the first phase of the Reformation not only the monasteries were liquidated, but the churches belonging to them were also demolished. This operation, initiated

9 Cattaneo E., L'intensità di una vita. Dalla nobilità alla porpora cardinalizia, [in:] Il grande Borromeo tra storia e fede, Cinisello Balsamo: Amilcare Pizzi, 1984, p. 63.

10 Martin G., Roma Sancta (1581), Roma: Edizioni di Storia e Letteratura, 1969, p. 54.

11 Karmon D., [in:] The Ruins of the Eternal City: Antiquity and Preservation in Renaissance Rome. Oxford: Oxford University Press, 2011, pp. 199-206.

12 Gay R., A Fools bold soon shott at Stonage. A Discourse concerning Stone-Age, [in:] Legg R. (ed.), Stonehenge Antiquaries, Sherborne: Dorset Publishing, 1986, p. 18; Walsham A., Sacred topography and social memory: Religious change and the landscape in Early Modern Britain and Ireland, Journal of Religious History, 36(1), 2012, p. 40. 
in 1538, and carried out extremely systematically under the direction of Lord Thomas Cromwell (1485-1540), generally aimed to seriously damage these buildings (Fig. 2), but not to demolish them completely ${ }^{13}$. As Alexandra Walsham has observed, what was thus intended was the "enduring evidence of Protestant glorious triumph over the forces of the devil and Antichrist", identified with corrupt "papist" Christianity ${ }^{14}$. During the civil war, from 1643 onwards, other mediaeval sacred monuments were destroyed, as they were considered to be "anti-Christian, diabolical and popish." However, those who directed this operation tried simultaneously "to prevent their utter ruin" in order to preserve the memory of corruption that produced them ${ }^{15}$.

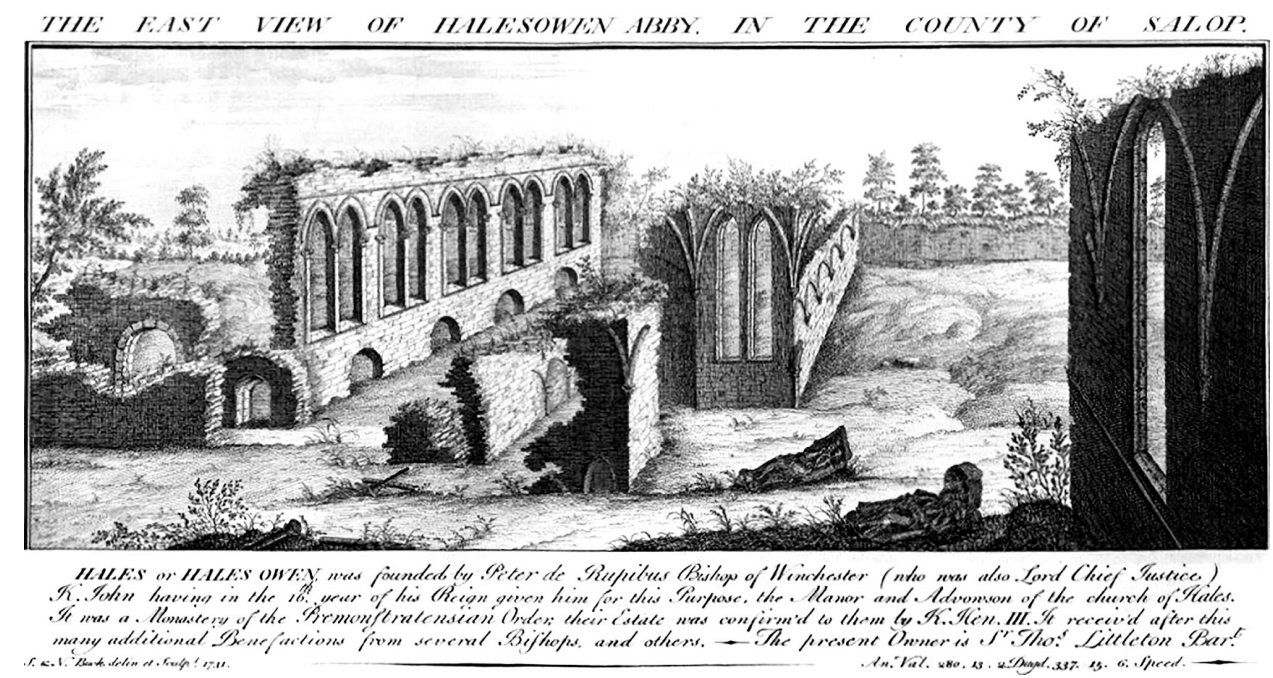

Fig. 2 Ruins of Premonstratensian Church and Monastery in Halesowen. Copperplate in: Samuel and Nathaniel Buck, Views of Ruins of Castles and Abbeys in England, vol. 2, 1731

During the introduction of the Reformation in Scotland in 1559-1562, crowds of its supporters not only "purified" numerous churches of paintings and sculptures, but also ruined these buildings, seeing them - persuaded by of Protestant preachers - as the "places of idolatry". The scale of destruction increased significantly in subsequent years of the religious confusion, in which the cathedrals and great monastic temples began to fall into ruin (Fig. 3) because of neglect, and in time also because they served as a source of construction materials obtained from them. After the situation has settled, parts of some of these buildings were rebuilt and adapted to serve as small parish churches in which the faithful gathered to follow the modest

\footnotetext{
13 Greene P., Medieval Monasteries, Leicester: Leicester University Press, 1982, pp. 178-180, 182-198.

14 Walsham A., Sacred topography and social memory: Religious change and the landscape in Early Modern Britain and Ireland, Journal of Religious History, 36(1), 2012, pp. 36-40; Sommerville C.J., The Secularisation of Early Modern England. From Religious Culture to religious Faith, Oxford: Oxford University Press, 1992, pp. 26-34.

15 Spraggon J., Puritan Iconoclasm during the English Civil War, Woodbridge: The Boydel Press, 2003, p. 240.
} 
Protestant liturgy. A large portion of the new churches literally grew out of the rubble ${ }^{16}$, and this made them eloquent symbols of the Reformed Church of Scotland, which - as the eminent theologian Thomas Chalmers (1780-1847) said in 1829 - managed to "overthrow the tyranny of the Anti-Christ and establish the fair and original form of Christianity on its ruins"17.

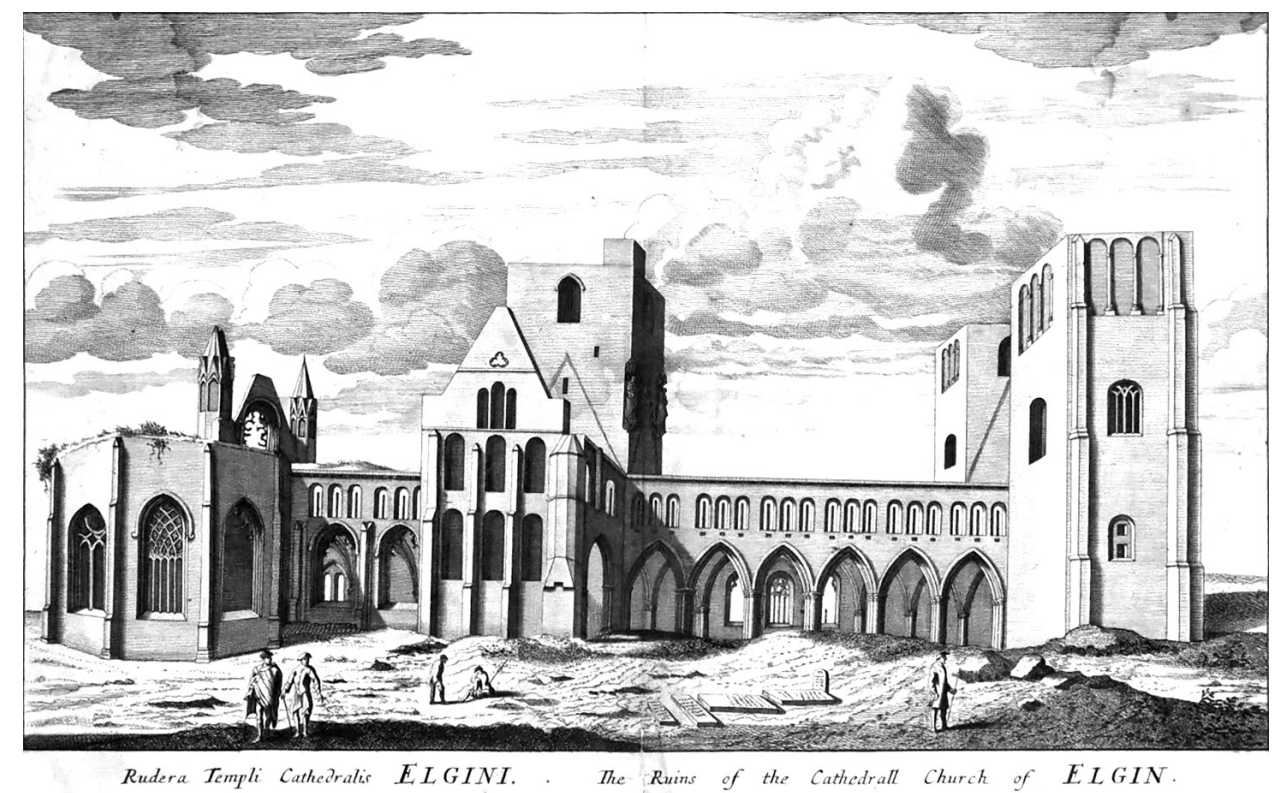

Fig. 3 Ruins of Elgin Cathedral, Copperplate in: John Slezer, Theatrum Scotiae, 1693

A considerable number of French temples turned to ruin during the Great Revolution, which fought against the Catholic Church as one of the pillars of the Ancien Régime that it sought to overthrow. After the secularization of church property in 1789, the systematic demolition of "unnecessary" temples was started under the supervision of state authorities, complemented by the more or less spontaneous demolition of churches by the radicalised groups of the sansculottes. A great many of these buildings, affected by the actions of the "iconoclasts", were not completely wiped off the face of the earth, but their relics were left, in which one could easily discern their former sacred function ${ }^{18}$. It is difficult to say unequivocally whether these actions were meant to convey a particular message to their audience, or whether they were the result of transforming many temples into quarries of sorts, from which it had not been

${ }_{16}$ McKean Ch., The Architecture of three religion: Scottish religious architecture after the Council of Trent, [in:] Chatenet M., Mignot C. (ed.) L'architecture religieuse européenne au temps des Réformes. Héritage de la Renaissance et nouvelles problématiques, Paris: Picard., 2009, p. 2013; Fawcett R., The Architecture of Scottish Medieval Church 1100-1560, New Haven: Yale University Press, 2011, pp. 393-400.

17 Kehoe S. K., Scottish Church: Catholicism, Gender and Ethnicity in Nineteenth-Century Scotland, Manchester: Manchester University Press, 2010, p. 39.

18 Réau L., Les monuments détruits de l'art français. Histoire du vandalisme, vol. 1, Paris: Hachette, 1959, pp. 286-366; Souchal F., Le vandalisme de la revolution, Paris: Nouvelles Editions Latines, 1993, pp. 49-58, 75-80. 
possible to "mine" the entire construction material before the collapse of the revolutionary authorities ${ }^{19}$. Nonetheless, the ruins of some churches, adapted provisionally for the purposes of the new Enlightenment cults and bearing inscriptions - like the one found in the remains of Saint-Thomas-de-Cantobéry collegiate church in Crépy-en-Valois - that "the French people profess faith in the Supreme Being and the immortality of the soul”20 (Fig. 4), can be regarded as a deliberately arranged illustration of the victory of the new revolutionary cults over the "superstitious Catholicism." After all, such works resonated in perfect harmony with the anthem by André Marie de Chénier (1762-1794), written for the ceremony of the "consecration" of the Paris cathedral as the Temple of Reason in 1793.

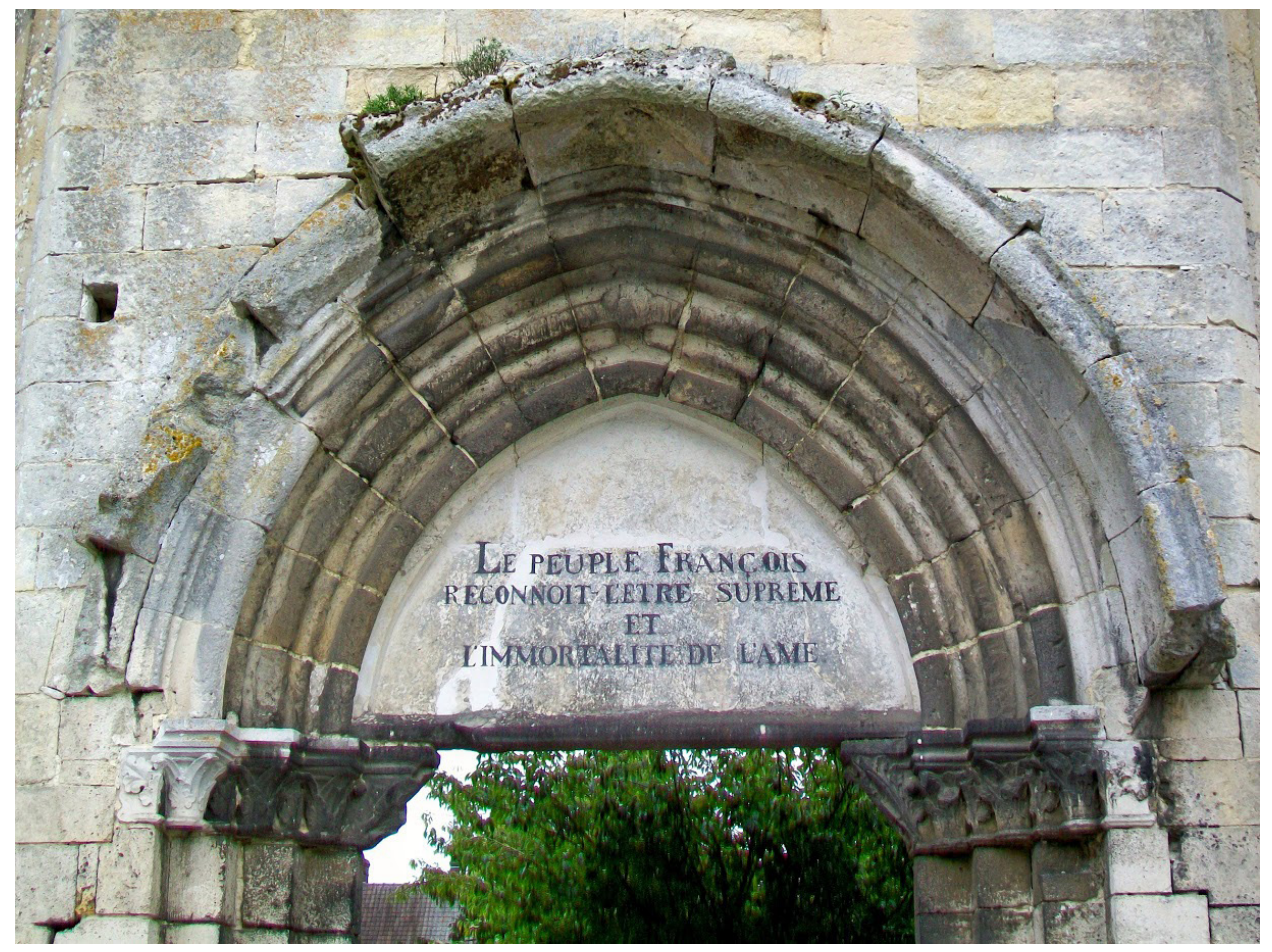

Fig. 4 Inscription of the portal of the Collegiate Church of Saint-Thomas-de-Cantobéry in Crépyen-Valois. Photo: Piotr Krasny

19 Fiango G., La conservazione e il restauro dei monumenti in Francia nella prima metà di XIX secolo, Restauro. Quaderni di Restauro di Monumenti e di Urbanistica dei Centri Antichi, 2(1), 1973, p. 10.

20 Réau L., Les monuments détruits de l'art français. Histoire du vandalisme, vol. 1, Paris: Hachette, 1959, p. 408; Souchal F., Le vandalisme de la revolution, Paris: Nouvelles Editions Latines, 1993, p. 76. 
Descend, o Liberty, thou child of nature! The people have recovered their power immortal!

On the majestic ruins of the old imposture Their hands erect thine altar ${ }^{21}$

It can be said with utmost certainty that in the nineteenth century, the ruins of French churches were widely attributed with some portentous meaning, while intense arguments continued about the definition of the particular message. In the current dispute of the time, which divided the French society, and concerned the place of the Church within the State, advocates of secularization pointed to post-revolutionary ruins as a clear sign of a happy release of society from the influence of Catholicism, and the radical rejection of religious heritage. People who advocated the strengthening of the said influence presented these relics as an example of the unimaginable barbarity of "iconoclasts", whose exploits proved conclusively that propagating godlessness obviously provokes "new vandalism" 22 . Such opinions were particularly numerously voiced during the discussion about the history of the ruins of the Benedictine church in Cluny, which for centuries had been one of the most important centres of religious life in France. During the intensification of the clerical policy of the Third Republic, attempts were made to actually assign a similar function to its remains, directing numerous pilgrimages thereto. In 1898 , these ruins also became a remarkable and very moving background for the celebrations of the ninth centenary of introducing All Souls' Day to the Catholic liturgy. Attended by large crowds of people, the celebrations served as an ostentatious demonstration of the strength of French Catholicism ${ }^{23}$.

"Fresh ruins" of French churches evoked "shock feelings" in Edmund Burke (1729-1797), who wrote, horrified, in his Reflections on the Revolution in France, published in 1790, that these remains "are sad, but instructive monuments" of revolutionary madness that spilled all over the country, enjoying the support of the authorities, and without encountering resistance on the part of the society ${ }^{24}$. The conservative English philosopher did not seem to notice that many sacred ruins emerged several hundred years earlier in his own homeland in very similar circumstances ${ }^{25}$. Such an attitude, however, was not necessarily merely a manifestation of hypocrisy, but it could also transpire from a new way of perceiving native remains of temples, which gained popularity in the eighteenth century in the British Isles. The religious zeal of the English and Scottish

${ }_{21}$ Pressensé de E., The Church and the French Revolution: A History of the Relations of Church and State from 1789 to 1802, Transl. Stoyan, J. London: Hodder \& Stoughton, 1859, p. 309.

22 Byrnes J. F., Catholic and French Forever: Religious and National Identity in Modern France, New Haven: Yale University Press, 2005, pp. 25-27, 74-75.

23 Marquardt J. T., From Martyr to Monument: The Abbey of Cluny as Cultural Patrimony, Newcastle: Cambridge Scholars Publishing, 2007.

24 Burke E., Reflections on the Revolution in France: and on the Proceedings in Certain Societies in London Relative to That Event, London: Penguin Books, 1969, p. 127.

25 Dent J., Sinister Histories: Gothic Novels and Representations of the Past, from Horace Walpole to Mary Wollstonecraft, Manchester: Manchester University Press, 2016, pp. 152-157. 
people was significantly weakened under the influence of the philosophy of the Enlightenment, which translated into the quietening down of anti-Catholic resentments ${ }^{26}$. As William Gilpin (1724-1804) remarked in his Observations on the Western Parts of England, Relative Chiefly to Picturesque Beauty, published in 1789, the British were increasingly forgetting that Catholic monasteries had been "great nurseries of superstition, bigotry and ignorance," and therefore they ceased to look at their ruins with a sense of vengeful satisfaction ${ }^{27}$.

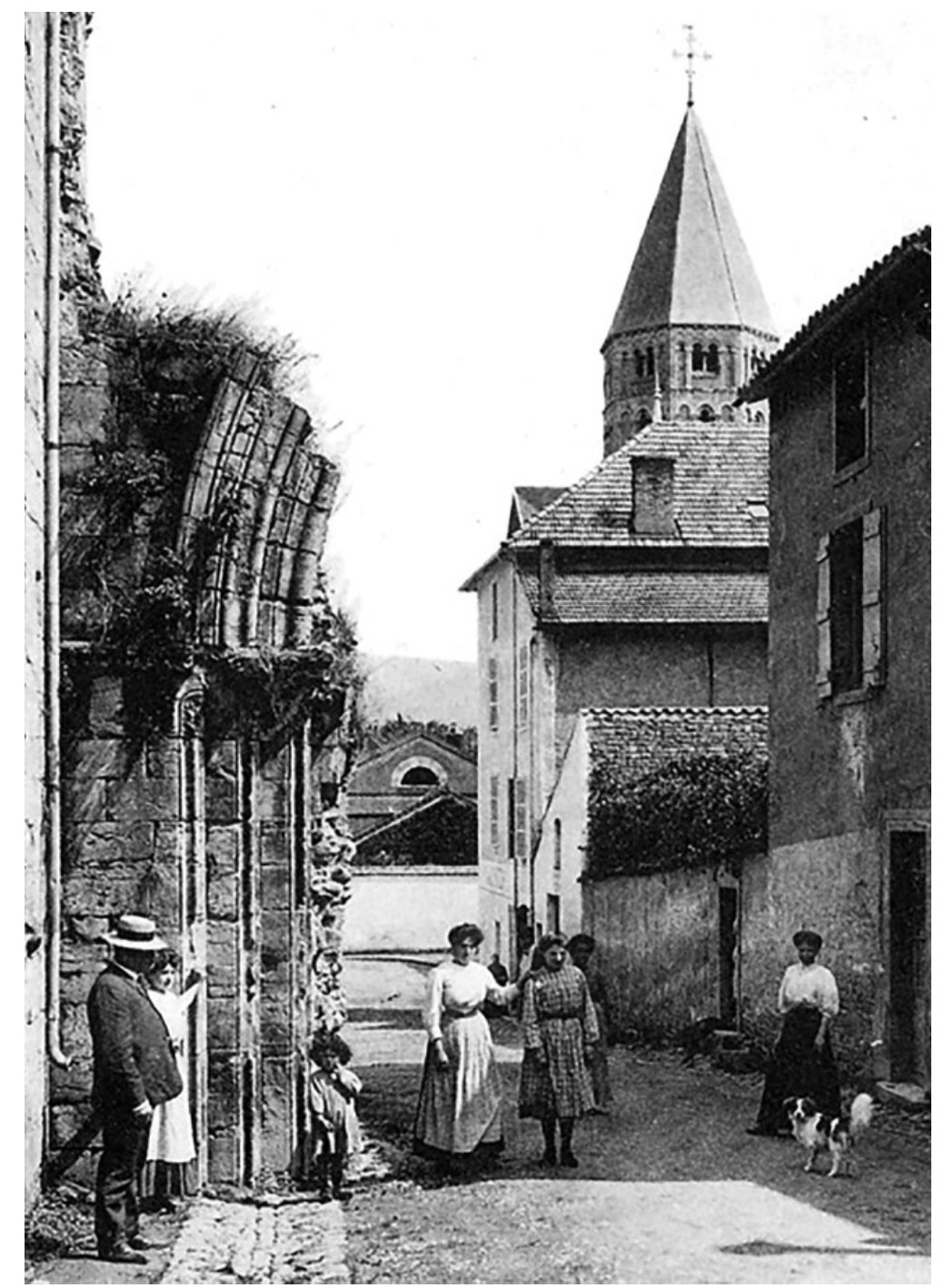

Fig. 5 Ruins of Benedictine Church in Cluny. Status c. 1920, Photo: Photo Library of the Institute of Art History, Jagiellonian University

26 Greene P., Medieval Monasteries, Leicester: Leicester University Press, 1982, pp. 200-201.

27 Gilpin W., Observations on the Western Parts of England, Relative: Chiefly to Picturesque Beauty, London: T. Cadell Jun. \& W. Davies, 1798, pp. 138-149; More R. E., Jane Austen and the Reformation: Remembering the Sacred Landscape, London: Routledge, 2016, p. 30. 


\section{Piotr Krasny}

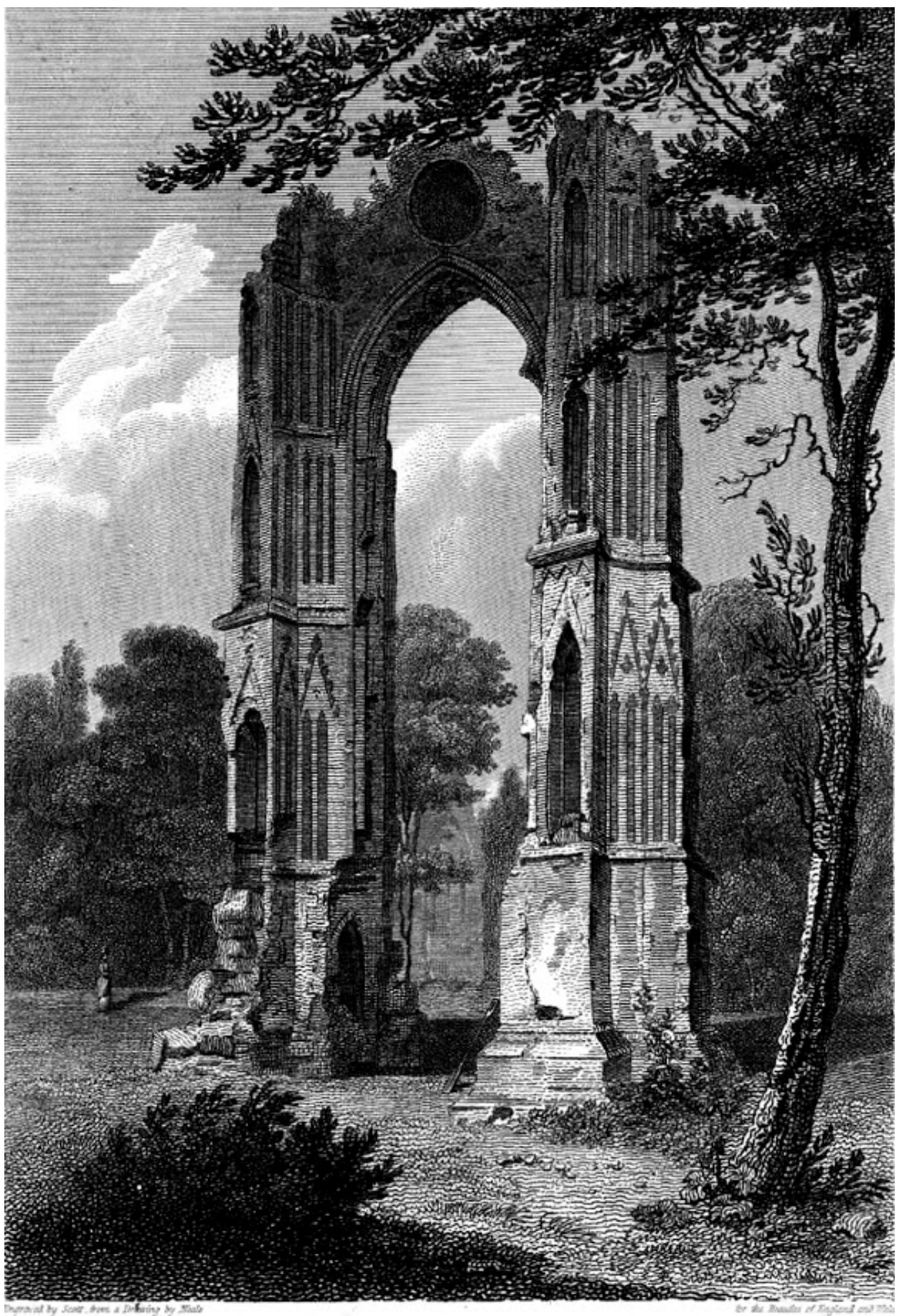

REMATYS. OF WALSINGHAM ABBEX, Norfolk.

Fig. 6 Ruins of the Church of Augustinian Canons in Walsingham. Woodcut of Scott after John Preston Neale, 1812 
This change often led to the intensified demolition of these relics, which were often treated simply as a source of cheap building material. For some church ruins, however, the weakening of their religious message proved to be beneficial. That is because poets who were indifferent to religion looked at them - as Gilpin put it - "with a picturesque eye"28, and they were striving to outdo each other in publishing "abbey meditation poems", describing the ruins as a nostalgic symbol of the not-so-dramatically experienced transience ${ }^{29}$ (Fig. 6). Copious number of aristocrats wanted to experience such emotions, proclaiming that the ruins of real buildings were more affecting than the artificial ruins, so fashionable at the time. For this reason, they tried to incorporate the remains of the old churches into their landscape parks, treating them only as a spectacular diversion amongst landforms of the terrain and exquisitely composed greenery $^{30}$. Therefore, John Aislabie's (1670-1742) statement that such "ruins generally appear the best at the distance", in fact described both the manner of their placement in the parks, and their place in the consciousness of this aristocrat's contemporaries. They were not very much interested in what function the ruined buildings had once performed or in what had led to their ultimate fall ${ }^{13}$. On the one hand, adapting church ruins to serve as peculiar park decorations contributed to the preservation of their material substance, but on the other hand, it led to them losing the values, which could be defined as spiritual or intangible.

Being mindful of this paradox seems especially important if we seek to elaborate reflection on the formula for dealing with church ruins in our contemporary times, in which the circumstances for their reception are shaped not only by religious indifference, but also by the progressive ignorance of the Christian tradition. Therefore, it should not be surprising that these relics are perceived only as picturesque details, distractions in the monotony of the landscape or the city skyline. This approach to sacred ruins reflected, inter alia, on the fate of the remains of the medieval church of Saint-Livier in Metz, deconsecrated in 1791, and from that moment onwards falling into ruin while being used for various secular purposes. In 1970, a large part of the building was demolished in order to make room for the construction of the luxury housing estate of Appartement Metz Pontiffroy ${ }^{32}$. The remains of the transept and part of the nave, though, were left in the square surrounded by residential buildings (Fig. 7), making it into a kind of a picturesque pergola, planted with various bushes, flowers and vines (Fig. 8). Thanks to this decision, the monotony of the modernist housing development was broken, and at the same time, significant parts of the medieval church were saved from complete destruction. The identity of these remains, however, was by no means obvious, since recently they had a banner flying from them showing a reproduction of the engraving with the view of the Saint-

28 Gilpin W., Observations on the Western Parts of England, Relative: Chiefly to Picturesque Beauty, London: T. Cadell Jun. \& W. Davies, 1798, p. 139.

29 Greene P., Medieval Monasteries, Leicester: Leicester University Pres, 1982, pp. 200-201; More R. E., Jane Austen and the Reformation: Remembering the Sacred Landscape, London: Routledge, 2016, pp. 24-32.

30 Watkin C. D., The English Vision. The Picturesque in Architecture, Landscape and Garden Design, London: John Murray Publishers, 1982, pp. 45-49; Greene P., Medieval Monasteries, Leicester: Leicester University Pres, 1982, p. 202.

31 Greene P., Medieval Monasteries, Leicester: Leicester University Pres, 1982, p. 202.

32 Vestiges de léglise Saint-Livier à Metz, Tout-Metz. Actualité Régionale et Agenda, February 25, 2015. 
Livier church soon after its desacralisation. There is little indication, however, that this picture, presented without any commentary, would encourage visitors to Pontiffroy to study one of the most magnificent temples that once existed in Metz ${ }^{33}$. Instead, these visitors are content with the statement - repeated on many occasions in various tourist websites - that they have come to "a nice solitary place (in the end, this is what churches are supposed to be)", [which] "seems a good place for meditation and self-reflection".

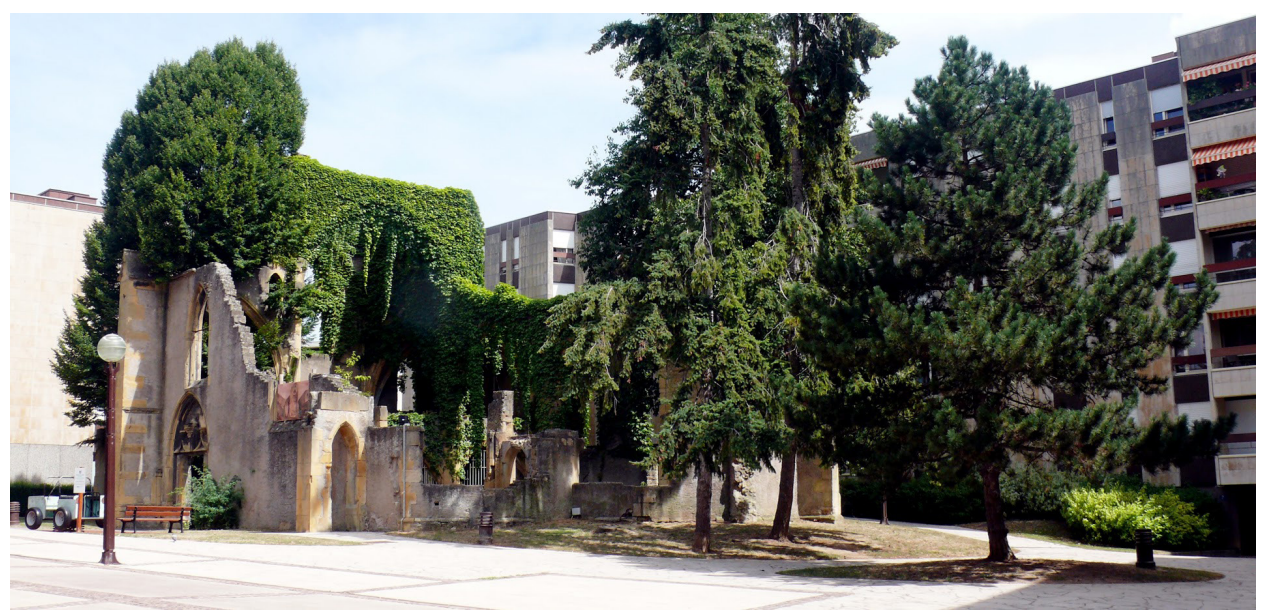

Fig. 7 Ruins of the Church of Saint-Livier in Metz. Photo: Piotr Krasny

For many centuries, the message of temple ruins had been read as a contrario sign of the power of religion, which was seen in these buildings before they were destroyed ${ }^{34}$. This meant that the remains of these churches were still attributed with a portentous meaning, which probably contributed to their preservation. Now, what will be the fate of sacred ruins, when we begin to approach them with indifference, checked at best by a note of sentimental reverie? The opinion of Julia Hell and Andreas Schönle that "ruins may signify the end of the old, or the beginning of something new" ${ }^{35}$ is particularly well suited to interpretations of the remains of sacred buildings, as they were pronounced over many centuries. When looking at how the ruins of Saint-Livier church in Metz were arranged, and reading about their reception, it is difficult to say what that "something new" might look like, either expressed or foretold by the current state of these remains. Therefore, there are many indications that the problem of perceiving, preserving and presenting church ruins must be carefully considered by all those involved in the protection of cultural heritage - the sooner the better.

33 Brachmann Ch., Tradition and innovation: Archbishop Chrodegang (742-766) and the Thirteenth-Century Family of Churches at Metz, Journal of the Warburg and Courtauld Institutes, 63, 200, p. 34.

34 Kleinbub Ch.K., Bramante's Ruined temple and the dialectics of the Image, Renaissance Quarterly, 63(1), 2010, pp. 438-441.

${ }_{35}$ Hell J., Schönle A., Acknowledgments, [in:] Hell J., Schönle A (ed.), Ruins of Modernity, (XIII-XV): Durham: Duke University Press, 2010, Vol. XIII. 


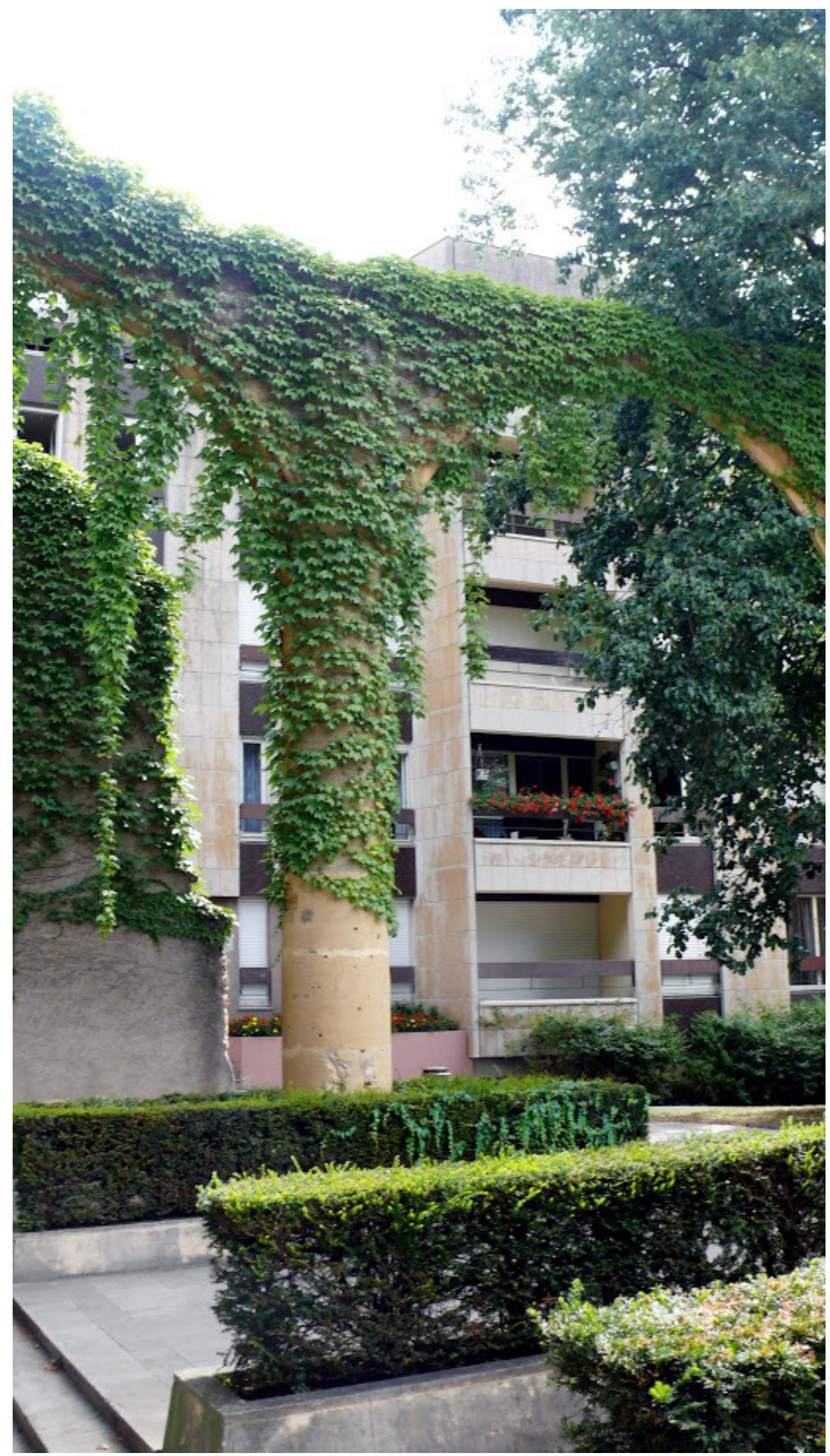

Fig. 8 Ruins of the Church of Saint-Livier in Metz. Photo: Piotr Krasny 


\section{Bibliography}

Brachmann Ch., Tradition and innovation: Archbishop Chrodegang (742-766) and the ThirteenthCentury Family of Churches at Metz, Journal of the Warburg and Courtauld Institutes, 63, 200, pp. 24-58.

Burke E., Reflections on the Revolution in France: and on the Proceedings in Certain Societies in London Relative to That Event, London: Penguin Books, 1969.

Byrnes J. F., Catholic and French Forever: Religious and National Identity in Modern France, New Haven: Yale University Press, 2005.

Cattaneo E., L'intensità di una vita. Dalla nobilità alla porpora cardinalizia, [in:] Il grande Borromeo tra storia e fede, Cinisello Balsamo: Amilcare Pizzi, 1984.

Dent J., Sinister Histories: Gothic Novels and Representations of the Past, from Horace Walpole to Mary Wollstonecraft, Manchester: Manchester University Press, 2016.

Fawcett R., The Architecture of Scottish Medieval Church 1100-1560, New Haven: Yale University Press, 2011.

Fiango G., La conservazione e il restauro dei monumenti in Francia nella prima metà di XIX secolo, Restauro. Quaderni di Restauro di Monumenti e di Urbanistica dei Centri Antichi, 2(1), 1973, pp. 3-76.

Gay R., A Fools bold soon shott at Stonage. A Discourse concerning Stone-Age, [in:] Legg R. (ed,), Stonehenge Antiquaries, Sherborne: Dorset Publishing, 1986.

Gilpin W., Observations on the Western Parts of England, Relative: Chiefly to Picturesque Beauty, London: T. Cadell Jun. \& W. Davies, 1798.

Ginsberg R., The Aesthetics of Ruins, Amsterdam: Rodopi B.V., 2004.

Greene P., Medieval Monasteries, Leicester: Leicester University Press, 1982.

Hell J., Schönle A., Acknowledgments, [in:] Hell J., Schönle A (ed.), Ruins of Modernity, (XIIIXV): Durham: Duke University Press, 2010.

Hertklotz I., Scavi, collezionisti ed eruditi nella Roma del Seicento, [in:] Hertklotz I., La Roma degli antiquari, Cultura e erudizione tra Cinquecento a Settecentom Roma: De Luca Editori, 2012.

Hui A., The Poetic of Ruins in Renaissance Literature, New York: Fordham University Press, 2017. Karmon D., [in:] The Ruins of the Eternal City: Antiquity and Preservation in Renaissance Rome, Oxford: Oxford University Press, 2011.

Kehoe S. K., Scottish Church: Catholicism, Gender and Ethnicity in Nineteenth-Century Scotland, Manchester: Manchester University Press, 2010.

Kleinbub Ch. K., Bramante's Ruined temple and the dialectics of the Image, Renaissance Quarterly, 63(1), 2010, pp. 421-458.

Martin G., Roma Sancta (1581), Roma: Edizioni di Storia e Letteratura, 1969. 
McKean Ch., The Architecture of three religion: Scottish religious architecture after the Council of Trent, [in:] Chatenet M., Mignot C. (ed.), L'architecture religieuse européenne au temps des Réformes, Héritage de la Renaissance et nouvelles problématiques, Paris: Picard, 2009.

Marquardt J. T., From Martyr to Monument: The Abbey of Cluny as Cultural Patrimony, Newcastle: Cambridge Scholars Publishing, 2007.

Montagu J., The Influence of the Baroque on classical Antiquity, [in:] Beck H., Sabine Schulze S. (ed.), Antikenrezeption im Hochbarock, Berlin: Gebr. Mann Verlag, 1989.

Montanari T., La libertà di Bernini. La sovranità dell'artista e le regole del potere, Torino: Giulio Einaudi Editore, 2016.

More R. E., Jane Austen and the Reformation: Remembering the Sacred Landscape, London: Routledge, 2016.

Piva P., L'altro Giulio Romano: Il Duomo di Mantova, la chiesa di Polirone e la dialettica di Medioevo, Quisnello: Ceschi, 1998.

Pressense de E., The Church and the French Revolution: A History of the Relations of Church and State from 1789 to 1802, Transl. Stoyan J., London: Hodder \& Stoughton, 1859.

Réau L., Les monuments détruits de l'art français. Histoire du vandalisme, vol. 1, Paris: Hachette, 1959.

Rossi Pinelli O., Chirurgia della memoria. Sculture antice e restauri storici, [in:] Settis S. (ed.), Memoria del antico nell'arte italiana, vol. 3, Torino: Giulio Einaudi Editore, 1986.

Sénéchal Ph., Resaturations et remplois de sculptures antiques, Revue de l'Art, 1988.

Seznec J., The Survival of the Pagan Gods: The Mythological Tradition and Its Place in Renaissance Humanism and Art, Transl. Sessions B.F., Princeton: Princeton University Press, 1995.

Sommerville C.J., The Secularisation of Early Modern England. From Religious Culture to religious Faith, Oxford: Oxford University Press, 1992.

Souchal F., Le vandalisme de la revolution, Paris: Nouvelles Editions Latines, 1993.

Sparti D. L., The Rebirth of ancient sculpture in 17th Century Rome, [in:] Bacchi A., Coliva A. (ed.), Bernini, Milan: Officina Libraria, 2018.

Spraggon J., Puritan Iconoclasm during the English Civil War, Woodbridge: The Boydel Press, 2003.

Tschudi V. P. , Baroque Antiquity: Archaeological Imagination of Early Modern Europe, Cambridge: Cambridge University Press, 2017.

Vestiges de l'église Saint-Livier à Metz, Tout-Metz. Actualité Régionale et Agenda, February 25, 2015. Walsham A., Sacred topography and social memory: Religious change and the landscape in Early Modern Britain and Ireland, Journal of Religious History, 36(1), 2012, pp. 31-51.

Watkin C. D., The English Vision. The Picturesque in Architecture, Landscape and Garden Design, London: John Murray Publishers, 1982. 